\title{
Features of the Commission of Fraud, Coupled with the Failure to Comply with the Provisions of a Civil Contract
}

\author{
Togaibayeva S. S. ${ }^{1}$, Yelyubayev M. S. ${ }^{1}$, Aikumbeckov N. ${ }^{2}$, Togaibayev A. I. ${ }^{3} \&$ Khanov T. A. ${ }^{4}$ \\ ${ }^{1}$ Kokshetauskiy University Abay Myrzakhmetova, Kokshetau, Kazakhstan \\ ${ }^{2}$ Caspian Public University's, Almaty, Kazakhstan \\ ${ }^{3}$ Department of Internal Affairs of the City of Karaganda, Karaganda, Kazakhstan \\ ${ }^{4}$ Karaganda Economic University of Kazpotrebsoyuz, Karaganda, Kazakhstan \\ Correspondence: Togaibayeva S. S., Kokshetauskiy University Abay Myrzakhmetova, Kokshetau, Kazakhstan. \\ E-mail: a.tytykalo07@gmail.com
}

\author{
Received: May 30, $2019 \quad$ Accepted: August 9, $2019 \quad$ Online Published: August 12, 2019 \\ doi:10.5539/jpl.v12n3p69 URL: https://doi.org/10.5539/jpl.v12n3p69
}

\begin{abstract}
The relevance of the study due to the need to consider the composition of a criminal offense in the form of fraud under the laws of the Republic of Kazakhstan. New market relations and insufficient legal regulation of certain aspects have expanded the offenders' ability to use the imperfections of legal norms for their own mercenary purposes. The difficulties arising in practical activities necessitate the clarification of controversial issues and the development of sound recommendations for the correct qualification and delimitation of fraud from other legal relations. Based on the study of practical examples of individual forms of fraud, the need for a differentiated approach to qualifications and the establishment of responsibility for fraud is indicated. The main content of the article is aimed at identifying and disclosing the basic concepts that determine the content of the considered offense and highlighting the main forms of deception that ensure the offender to achieve a criminal result. The objective and subjective characteristics of the composition of fraud are investigated, the features of establishing individual qualifying characteristics are considered. The main method of research used a comparative legal analysis of domestic legislation, used statistical data and the results of a survey of law enforcement officers.

The article touches upon the problem of non-fulfillment of contractual obligations as a sign of fraud in the business sphere. Identified and investigated some signs of the objective side of fraudulent activity, in which as a cover for illegal actions, the use of civil law contracts that facilitate the commission of fraud is used. It justifies the conclusion that, taking into account the signs of the objective side, the moment of the end of fraud, coupled with non-fulfillment of contractual obligations, is different from the moment of the end of the usual fraud. Article materials may be valuable for practitioners of pre-trial investigations in terms of scientifically based proposals and recommendations on the qualification of typical fraudulent acts veiled under a civil law transaction.
\end{abstract}

Keywords: fraud, active deception, passive deception, misrepresentation, failure to fulfill contractual obligations, civil-law contract

\section{Introduction}

In the context of ongoing crisis in the economy, the growth of uncontrolled internal migration in the country, the concentration of financial flows in various major cities of the Republic of Kazakhstan, there is an acute problem of protecting property as the basis for the welfare of individuals, society and the state from criminal encroachment.

The increase in the number of property disputes in the courts, based on, as a rule, mercenary motives of fraud, confirms the relevance of the analyzed issue. From 1998 to 2016 there is an increase in the number of registered frauds by more than 10 times. For example, if in 1998 there were only 3,047 registered, then in 2016 there were 30,358 fraudulent actions (data from the Committee on Legal Statistics and Special Accounting of The General Procurement of The Republic of Kazakhstan).

Also, this type of crime is a fairly significant percentage in the overall structure of the committed offenses. So, 
the analysis over the past five years shows the following: in 2012, out of 287,681 criminal offenses were registered in the Republic of Kazakhstan, 23,262 (8\%) of frauds were committed; in 2013, out of 359,844 registered criminal offenses, fraud amounted to 36,405 (10.1\%); in 2015, out of 3,46510 under Article 192, a total of -37729 (10.8\%) offenses were registered; in 2016, out of 3,61689, 30,358 (8.3\%) of fraudulent acts were committed; Finally, in 2017, 316418 of them were registered - 27,467 (8.6\%) accounted for fraud in various fields (Statistical reporting in the Republic of Kazakhstan. Prosecutor General's Office of the Republic of Kazakhstan. Period of 2012 -2017).

The data show that fraud in the overall structure of crime steadily ranges from 8 to 10.8 percent, which indicates a significant prevalence and public danger of this type of offenses against property. In addition, fraudulent acts are committed both in respect of individuals and legal entities. It is common in the field of economic and business activities, in the field of credit, in the field of public procurement.

In the practical activities of law enforcement agencies and courts of the Republic of Kazakhstan, there are problems of distinguishing criminal cases of fraud from civil law relations, and it becomes difficult to establish distinctive signs of fraud from other forms of theft. There are controversial situations in qualifying fraud committed by the subject of corruption. In connection with the expansion of the legal list of issued securities, there has been a tendency to commit fraudulent acts with insider information (Emelyanova, 2013:24; Togaibaeva, Togaibaev, Khanov, Sikhimbayev \& Rustemova, 2016:10201). Most of these circumstances cause difficulties in identifying signs of fraud and bringing perpetrators to justice.

In order to clarify the issues of separating fraud from other elements of criminal offenses and form a unified approach to the qualification of fraud, Kazakhstan adopted the Regulatory Resolution of the Supreme Court of the Republic of Kazakhstan dated June 29, 2017 No. 6 "On judicial practice in cases of fraud" (Regulatory Resolution of the Supreme Court of the Republic of Kazakhstan dated June 29, 2017 No. 6 "On Judicial Practice in Fraud Cases").

However, despite the measures taken, many issues related to the determination of qualifying signs, proving the composition of a criminal offense, the establishment of elements of a criminal offense, cause difficulty both in theory and in practice of the bodies of criminal prosecution and the court.

\section{Materials and Methods}

Since criminal fraud is manifested in many areas of human activity, fraud has covered a fairly wide range of public relations and more and more people are involved in it. To confirm this trend we will give some examples from practice.

For example, a fraud case was investigated in Astana, in which at least 100 deceived people were involved. The attackers urged the gullible Astana residents to apply for loans and promised that there would be no problems with repayment.

People as a reward paid from 10 to 20 percent of the loan. The rest of the money was scammed by the fraudsters. Thus, some of the victims were issued several loans at once - up to 10 loans. For example, one of the victims, citizen J., received loans from nine banks. The total amount of all loans amounted to five million tenge (Up to 10 credits per person: case details, 2018).

Another similar example. Astana policemen detained a woman who was convincing people to take knowingly bad loans. She was citizen M., who from 2012 to 2014 deceived more than a hundred people. Proved more than 500 episodes of fraud worth more than 350 million tenge. With the sentence of Saryarki Court No. 2 of Astana, M. M. was sentenced to four and a half years in prison with confiscation of property (A woman deceived people for 350 million was convicted, but banks still demand repayment of loans from victims in Astana, 2018).

In recent years, a fraudulent scheme for obtaining non-performing loans has been developed in the Shymket region. More than two million tenge was stolen by credit fraudsters in the Shymket branch of one of the country's banks.

Ways to commit fraud in order to obtain a loan consisted in forging technical documentation, in particular, technical passports, acts of acceptance of real estate objects into operation. Through forged documents received loans in large amounts. Each borrower on average fraudulently received a loan in the amount of 4 to 20 million tenge. Often, as a pledge, there was an adobe temporary house, which could not serve as collateral for a bank. Using their connections in private and public institutions, by fraud, intermediaries forged documents on real estate, overstating real value on real estate. Credits were processed through bank managers; money was immediately cashed out. The investigative department of internal affairs of the South Kazakhstan region registered more than 200 criminal cases on the grounds of crimes provided for by article 177 of the Penal Code 
of the Republic of Kazakhstan "Fraud", where the bank is the victim (Dobrota, 2016).

One of the most dangerous forms of fraud today is the extraction of financial data. Fraudsters are often asked to send a photo of the check or receipt, confirming payment in electronic form of certain services.

So, one of the victims was informed that the Samsung Galaxy S8 phone would be sent to him on condition that he would make an advance payment in the amount of 36 thousand tenge "to pay the tax" and send a photo of the receipt. Allegedly, he was the winner and participated in the raffle of the car, which will be held on the air of the radio "Retro FM" on the same day (Fraudsters in North-Kazakhstan region cheat residents with the help of popular portals and participation in sweepstakes). It should be noted that one of the clear signs of possible fraud committed with the help of false ads, is the requirement of prepayment.

Recently, the so-called black realtors, fraudsters engaged in scams with the sale of real estate have intensified. The loud process took place in the Kostanay region. The convicted gang of "black realtors" for ten years deceived socially unprotected citizens - graduates of orphanages and the disabled. In the arsenal of the participants in the criminal group there were various methods - psychological pressure, violence, deception, abduction of apartment owners, falsification of documents for real estate, unlawful deprivation of liberty (Enshina, 2015, 6 May).

A loud trial was held in the city of Karaganda. According to the case file, fraudsters-realtors rented out non-existing apartments to clients. A statement to the law enforcement authorities appealed to about 180 victims, who showed that within six months, real estate offices collected from customers 8 thousand tenge for services, but in fact provided non-existent phone numbers (In Karaganda, realtors-fraudsters appeared in court).

As can be seen from the above examples, fraudsters operate in all areas. Since the extent of damage and the scale of consequences are different, we consider it logical to change the approach to sanctions of articles imposing punishment for fraud, and it is also advisable to consider introducing new, qualifying elements of criminal offenses related to fraudulent acts to the CC RK.

In particular, the correctness of such a statement of the question is confirmed by a conducted survey of law enforcement officers. Thus, the data obtained indicate that $46 \%$ of the respondents considered acceptable the introduction of changes and amendments to the Criminal Code of the Republic of Kazakhstan. In particular, the majority supported the establishment of criminal liability for fraud in the insurance and business sectors.

In order to understand the current situation, we consider it necessary to carry out a comparative legal analysis of the norms of domestic legislation, to consider the available scientific approaches on the issue being investigated and, using the results obtained, to propose solutions.

\section{Results}

Despite the adoption on July 3, 2014 of the new Criminal Code, enacted on January 1, 2015, in Kazakhstan there are difficulties in qualifying the acts in current question.

Criminal liability for fraud under Art. 190 of the Criminal Code of the Republic of Kazakhstan. In accordance with the law, fraud means the theft of another's property or the acquisition of the right to another's property by fraud or abuse of trust.

The Code provides for five qualifying features:

1) by a group of persons by prior agreement;

2) repeatedly;

3) a person using his official position;

4) by deceiving or abusing the trust of the information system user;

5) in the field of public procurement (Part 2 of Art. 190 of the Criminal Code of the Republic of Kazakhstan).

Of these signs, a certain difficulty in qualifying is presented in clause 4 of part 2 of the article under review, since it is difficult to establish the circumstances of the fraud by deceiving or breaching trust in the face of an information system user. In this case, should be guided by paragraph 29 of Art. 1 of the Law "On Informatization" (Law of the Republic of Kazakhstan on November 24, 2015 No. 418-V "On Informatization"). In accordance with this law, a user is recognized as a subject accessing an information system for obtaining the necessary electronic information resources and using them. Therefore, to bring to criminal responsibility for a given qualifying attribute, it is necessary to establish that a specific person intentionally used information systems to commit theft, either by deception or abuse of the victim's trust, to facilitate his criminal intent. 
An attempt to clarify the specified qualifying attribute was attempted by the Supreme Court of the Republic of Kazakhstan. In its Regulatory Resolution of June 29, 2017 No. 6 "On Judicial Practice in Fraud Cases", the following explanation was given. "... Under fraud committed by deceiving or abusing the trust of the information system user, the actions of the perpetrator aimed at taking possession of the property or the right to the property of the information system user committed through information technologies (computer, computer programs, Internet, cell phone, etc.) should be recognized. ), by placing in the information system deliberately inaccurate information or programs, in order to implement his criminal intent to deceive the user through Qiwi-purse, online banking, and so on. d. "( Regulatory Resolution of the Supreme Court of the Republic of Kazakhstan dated June 29, 2017 No. 6 "On Judicial Practice in Fraud Cases").

In cases where the said acts involve unlawful access to an information system or a telecommunications network, the offense is subject to qualification on the totality of criminal offenses under Articles 190 and 205 of the Criminal Code, or 190 and 206 of the Criminal Code, if as a result of the unauthorized access to computer information, violation of the computer, computer systems or their networks ( Regulatory Resolution of the Supreme Court of the Republic of Kazakhstan dated June 29, 2017 No. 6 "On Judicial Practice in Fraud Cases").

Thus, this explanation directly indicated the need to prove as the fact of the fact that an attacker deliberately inaccurate information or programs was placed in the information system, as well as the fact that they were established precisely for the purpose of implementing the criminal intent to deceive the user. Therefore, the presence of a person of the appropriate program cannot testify about his criminal intent, it is necessary to prove both the first and second circumstances.

In cases where the fact of deception through the use of information systems cannot be proved, for example, in connection with the removal of false information, then bringing a person to responsibility causes great difficulties. In addition, fraudsters often create fake pages using sites and design of well-known companies. In this regard, often the claims are made officially by the operating company, and while its activity is being checked, fraudsters destroy all the compromising information and delete the identification data from electronic information resources. After a certain time, it is rather difficult to establish incriminating information and gather evidence of the commission of illegal actions with the use of the information system by hackers.

Therefore, an important circumstance for bringing such fraudsters to criminal responsibility is speed of response, prompt collection and copying of all available disclosing information, excluding the possibility of editing. If possible, the cooperation with the provider, which, as a rule, does not give confidential information, so obtaining primary sources is difficult. The absence of highly qualified information technology specialists in the law enforcement system also impedes obtaining evidence that exposes a person to commit fraud using electronic information resources.

In recent years, there have been frequent cases of fraud in public procurement. In this regard, paragraph 2 of Article 190 of the Criminal Code of the Republic of Kazakhstan includes clause 5, providing for the qualifying sign "fraud in the field of public procurement".

Despite the introduction of criminal liability, it is also very difficult to prosecute on this qualified basis, since it is difficult to prove the fact of deliberate deception or misrepresentation of tender participants.

It should be borne in mind that the legal relations in the field of public procurement are regulated by the Law of the Republic of Kazakhstan "On public procurement" dated July 21, 2007 (Law of the Republic of Kazakhstan dated December 4, 2015 No. 434-CC RK "On Government Procurement"). In accordance with paragraph 18 of Art. 1 of the Law, government procurement refers to the purchase by customers of goods, works, services necessary to ensure the functioning, as well as the performance of public functions or statutory activities of the customer, carried out in the manner prescribed by this Law, as well as the civil legislation of the Republic of Kazakhstan.

In the same Regulatory Resolution dated June 29, 2017 No. 6, the Supreme Court of the Republic of Kazakhstan in paragraph 16 gave the following clarification:

"... Under the fraud in the field of public procurement refers to the actions of the perpetrator (supplier), including the presentation of deliberately false information (about the financial or economic situation, the presence of workers, technical equipment, etc.), with the aim of deception, which are intentionally misleading the customer or the organizer of public procurement in order to convert budgetary funds in favor of or for the benefit of third parties, as a result of which the supplier, without delivering the goods or performing the work, or without service, assigns the allocated funds.

In cases when the authorized person of the customer knowingly prepares a fictitious act of acceptance-transfer of 
goods or work performed or services rendered, after which the supplier's account receives funds that the supplier draws into his property and disposes of them at his own discretion, then such actions of the supplier do not form the composition of fraud. Depending on the established circumstances, these actions (authorized persons of the customer or supplier) can be qualified as abuse of official position or theft of someone else's entrusted property by misappropriation or embezzlement " ( Regulatory Resolution of the Supreme Court of the Republic of Kazakhstan dated June 29, 2017 No. 6 "On Judicial Practice in Fraud Cases").

At the same time, the law excludes from this sphere legal relations related to the provision of services acquired from individuals under employment contracts and services acquired from individuals who are not subjects of entrepreneurial activity under contracts of compensated provision of services.

Along with this, the purchase of goods, works, and services within the framework of the fulfillment of the state task in accordance with the budget legislation of the Republic of Kazakhstan is excluded from the list of public procurements. Also excluded are procedures related to making contributions (contributions), including to the authorized capital of legal entities (Law of the Republic of Kazakhstan dated December 4, 2015 No. 434-CC RK "On Government Procurement").

Thus, as a subject of fraudulent actions, only the supplier is represented, and it also limits his criminal activities to the presentation of deliberately inaccurate information. Consequently, the use of other criminal schemes that do not fall under these signs precludes the bringing of a person to criminal responsibility for fraud. Such an approach does not fully meet the task of countering fraud in the field of public procurement, since actions veiled under lawful activities or fictitiously subject to tender conditions, but created to commit a fraud, can no longer be held criminally liable.

Part 3 of Article 190 of the Criminal Code of the Republic of Kazakhstan identifies especially qualifying signs of fraud: large-scale fraud; a person authorized to perform public functions, or an equivalent person, or an official, or a person holding a responsible government position, if it involves his official position; in respect of two or more persons. Part 4 of Art. 190 of the Criminal Code of the Republic of Kazakhstan provides for liability for the acts provided for in the first, second or third parts of this article, if they are committed: by a criminal group; on a large scale.

These qualifying signs do not cause any special difficulties in bringing to criminal responsibility; therefore, we will not dwell on them.

Also, there is no difficulty in the general subject of fraud, which is recognized as a natural sane person who has reached the age of 16 .

Meanwhile, there are difficulties with the definition of the concept of "deception" or "abuse of trust" in the commission of fraudulent acts aimed at stealing someone else's property or acquiring the right to someone else's property. In this regard, it is necessary to clarify the concept of fraud, since the concept of "fraud" is not explained in the criminal code of the Republic of Kazakhstan.

It should be noted that earlier the Criminal Code of the Russian Soviet Federative Socialist Republic of 1923 contained a footnote to Art. 187, in which it was explained that deception is considered to be both a report of false information, and a deliberate concealment of circumstances, the report of which was necessary.

Despite the fact that the above Normative Regulation of the Supreme Court also clarifies that “... deception is a way to commit fraud in order to steal someone else's property or to acquire the right to someone else's property. Deception may consist of deliberately misleading the owner or other property owner of a property by knowingly false information that does not correspond to the facts or concealing the true facts that should have been reported to the property owner or another person's erroneous idea of legality. transfer of property to the possession of the guilty person and (or) other persons " ( Regulatory Resolution of the Supreme Court of the Republic of Kazakhstan dated June 29, 2017 No. 6 "On Judicial Practice in Fraud Cases"), however, there is no generally accepted point of view in the legal literature on this issue.

Especially significant disagreements exist on the issue of forms of fraud, which is presented either by committing active actions or abstaining from any actions (passive deception).

In particular, I.Sh. Borchashvili believes that deception is understood as the intentional misrepresentation of a person regarding any circumstances, facts or a conscious silence about them in violation of the legal obligation (Borchashvili, 2015:491).

V. Khilyuta shares this point of view, calling the silence about the truth a passive form of deception (Khilyuta, 2017:112). 
Some authors categorically deny the presence of a passive form of deception. So in particular S.V. Veklenko and S.A. Petrov, directly indicate that "... if deception is the purposeful influence of the guilty on the psyche of the subject of influence, then it cannot be committed by inaction. The use of another's delusion is not included in the content of the word "deception" used in the Russian language. Passive deception is not an action, it is a state into which the victim himself has introduced himself, therefore it is not a deceit" (Veklenko \& Petrov, 2011:11). In connection with the above, these authors recognize that there is only one form of deception - active.

In this regard, the question arises whether deception can occur in a passive form, through silence about the truth. We will consider it in more detail.

\section{Discussion}

V.V. Khilyuta believes that "... silence about truth as a form of deception can occur when the circumstances of the case are silent (notorious for the perpetrator, due to conclusive actions, etc.) used by him and testifies to the counterparty to conclude a deal (contract) by approving or denying any fact. " In support of his innocence, he gives an example when a person offering to buy property, thereby confirms the legitimacy of owning it and does not inform the buyer about the real owner of the property at the time of the transaction (Khilyuta, 2017:113).

It should be noted that the criminal law of the Russian Empire also recognized a passive deception, but it was assumed that the criminal silence of truth should not be considered any actions, but only those that are "put under legal protection" (Foynitski, 1871:83-84). Meanwhile, the Soviet doctrine of criminal law based on the postulate that every crime is a violation of moral norms, in other words, the subject is recognized as obliged to tell the truth in all cases when it puts the victim in a situation that is extremely unfavorable for him (Borzenkov, 1971:14).

Soviet criminal law fraudulently acknowledged the use of the delusion of another person, which arose independently of the behavior of the criminal. So, according to some scientists, the appropriation of property, unnecessarily received by a private person as a result of a mistake realized by him, committed by an official who performed the property distribution (for example, misappropriation of the amount of money received in the savings bank) should be qualified as fraud (Gelfer, 1987:29).

However, according to V.V. Hills, actions of the guilty fall under the signs of theft by deception, only if the victim's mistake or delusion was caused or supported by the guilty himself. When a mistake or delusion arose regardless of the actions of the perpetrator, who, while receiving the property, kept silent about the fact that he was given the wrong, the composition of fraud is absent (Khilyuta, 2009:15).

Thus, it is necessary to agree that the perpetrator, in the passive form of fraudulent deception, uses the ignorance, inexperience, and deceit of the victim, is silent about the circumstances, the report of which was obligatory, in the result of which the person at the time of the transfer of the property is mistaken about the existence of legal grounds for the transfer of this property (Khilyuta, 2007:70).

According to A.A. Borovkov, guilty of committing fraud, is silent about the relevant circumstances, without informing the information that the person should have reported, deceiving either reinforces such a mistake, or sometimes contributes to its occurrence (Borovkov, 2018).

Clause 12 of the normative resolution of the Supreme Court of the Republic of Kazakhstan No. 6 of June 29, 2017, "On Judicial Practice in Fraud Cases", explains: “... illegal receipt of social benefits and allowances, remittances, bank deposits or other property from mercenary on the basis of other people's personal or other documents (for example, a pension certificate, birth certificate of a child, a bank savings book, in which the name of its owner is indicated, or other registered security and etc.) forms the composition of fraud "( Regulatory Resolution of the Supreme Court of the Republic of Kazakhstan dated June 29, 2017 No. 6 "On Judicial Practice in Fraud Cases").

Vladimirov V.A. believes that inaction with deception can have a diverse value and be expressed in various forms:

a) a deliberate silence of the guilty about the circumstances, ignorance of which led to the emergence of a delusion from the victim regarding the legality of the transfer of property to the guilty person;

b) the conscious use of another's delusion, as a result of which the guilty received property from the erroneous victim.

When passively deceiving, the person is not specifically informed about certain facts or specific circumstances, because knowledge of them could stop him from making a deal or significantly affect the terms of the agreement (Vladimirov, 1974:23). 
An example of passive deception is when a seller hides the unsuitability of a thing for practical use or does not report any of its significant shortcomings, which are known to him in advance, or sells a brass product at the price of gold.

Thus, it is necessary to recognize the presence, along with the active form of deception, a passive deception, consisting in the silence of certain circumstances or information that should have been communicated before the conclusion of the transaction. At the same time, there should be a delusion of a person regarding the facts that are important for making a decision on the transfer of property or the right to it.

Often in practice there are cases of bringing to criminal responsibility of individuals for non-payment of a consumer loan in a timely manner. In this regard, it is necessary to understand whether such actions entail responsibility for fraud.

At the same time, it is necessary to distinguish fraud from illegal receipt of a loan or misuse of a budget loan (Article 219 of the Criminal Code of the Republic of Kazakhstan).

The criteria for distinguishing between these crimes are the intent and the time of its occurrence.

Usually, the prosecution faces serious difficulties in proving the fact of fraud at the time of receiving the loan. This type of fraud is called fraud. Its essence boils down to the fact that already at the moment of receiving a loan (agreed amount) the person is not going to return the debt, but intends to use it at his discretion. In these cases, as a rule, taking possession of another's property occurs precisely through deception, and not the abuse of trust.

Some legal scholars believe that in the absence of fraud in intentions at the time of receiving a loan (advance), the subsequent failure to fulfill the obligation, even deliberately, in principle cannot be considered as fraud due to the absence of the subject of theft. Money received in debt, either as an advance or a prepayment, at the time of their receipt becomes the property of the debtor, the lender loses the rights to this money. Non-fulfillment of the obligation does not entail and cannot entail the acquisition by the debtor of any rights to any property (Brilliantov, 2015:493).

Meanwhile, among scientists there is a dispute about what to consider as "non-fulfillment of contractual obligations".

Some authors believe that if one understands the sign "non-fulfillment of contractual obligations" narrowly (that is, from the point of view of the principle of real execution), then in cases when the obligation was fulfilled, but not with the object, not at that time or in that volume the composition of entrepreneurial fraud will not be, since the actual execution took place (Mirochnik \& Borovkov, 2017:96).

Other authors believe that within the framework of fraud, involving non-fulfillment of provisions of a civil contract, the law enforcer should proceed from the fact that the objective side of a crime can form both non-fulfillment and improper fulfillment of contractual obligations (Zhalinskiy, 1999:48).

However, the analysis of judicial practice showed that the courts qualified actions as fraud, not only related to the failure to fulfill contractual obligations, but also in improper performance.

So, as a confirmation of the validity of this court practice, the following examples are given:

By the verdict of the Leninsky District Court of the city of Orenburg, it was established that the director of Ltd "A" had concluded an agreement with the director of Ltd "B" for the supply of materials for the upper structure of railway tracks. In pursuance of the agreements reached at the time of signing the supply agreement, as a prepayment, Ltd "B" has transferred money. Ltd "A" purchased from OJSC "P" a small batch of materials for railway track superstructure for the delivery of Ltd "B", after which Ltd " $\mathrm{A}$ " evaded the fulfillment of its obligations under the contract, and the amount previously transferred as a prepayment, the director Ltd. "A" ordered further at its sole discretion (The verdict of the Leninsky District Court of Orenburg on March 12, 2013 in the case of 1-101 / 2013).

In another case, between Ltd "N" in the person of K. A. and OJSC "B" in the person of V. V. a contract for the supply of buckwheat was concluded. The raw materials were supplied by OJSC "B", and the funds for it were transferred by Ltd "N". Then K.A. suggested that the representative of OJSC "B" purchase from him an additional batch of buckwheat at a price below the market price. After receiving the consent, they signed an additional agreement to the previously concluded contract. OJSC "B" made an advance payment for the delivery of products. However, K.A. did not comply with the terms of the contract, having implemented its criminal intent, the products for OJSC "B" were not delivered. At the same time, K.A. transferred the funds transferred to the current account at his own discretion (The verdict of the magistrate of the court area No. 5 of the Central 
District of Barnaul dated March 14, 2013 in case No. 1-9 / 2013).

According to A.S. Mirnochnik and A.A. Borovkov, despite the fact that in the examples given, the fulfillment of obligations under the contract actually took place, but it was only partial, and was carried out improperly (Mirochnik \& Borovkov, 2017:96).

We share the views expressed. However, the question arises: will any improper performance of contractual obligations be indicative of signs of fraud?

In this regard, it should be noted that there is a point of view according to which not all inadequate fulfillment of contractual obligations would correspond to the public danger that allows such a violation to be recognized as a crime, and not a civil-law delict. According to some legal scholars, the composition of this type of fraud will appear only with a significant violation of the terms of the contract (Kiseleva, 2013:88; Khanov, Bakishev \& Veselskaya, 017:16).

At the same time, the conditions associated with the subject matter of the contract should be considered significant. These conditions, as a rule, are directly stipulated by those in the law, other legal acts, or they are necessary for the conclusion of contracts of a certain type. Or, these are the conditions regarding which, according to the statement of one of the parties, an agreement should be reached (Yani, 2015:22).

However, such an approach, in our opinion, is not true, since the fact of the violation of the terms of the contract, even if it is significant, does not yet indicate that the person intends to deceive the counterparty. Failure to comply with the conditions may arise for various reasons, both objective and subjective. Moreover, if at the time of the conclusion of the contract or when preparing it, no fraud was made, then criminal prosecution under Art. 190 of the Criminal Code of the Republic of Kazakhstan should be declared illegal.

A similar position is taken by the Supreme Court of the Republic of Kazakhstan. Thus, paragraph 10 of the regulatory resolution dated June 29, 2017 No. 6 "On Judicial Practice in Fraud Cases" states that in order to distinguish fraud from civil law relations, it should be taken into account that when fraud is intended, it is aimed at stealing someone else's property or acquiring the right on someone else's property by fraud or abuse of trust, arises from the guilty person before and (or) at the time of the conclusion of the contract, providing for obtaining someone else's property or the right to it (Regulatory Resolution of the Supreme Court of the Republic of Kazakhstan dated June 29, 2017 No. 6 "On Judicial Practice in Fraud Cases").

A mandatory condition for bringing to criminal responsibility in such cases is the need to prove that the fraudulent actions of the perpetrator preceded the transfer of this property or the acquisition of the right to it and are in causal connection with the fact that the guilty received the property or the acquisition of the right to the property.

If it is established that the contract between the parties was concluded with the mutual intentions of the parties to fulfill the relevant obligations, but after its conclusion and receipt of material benefits, one of the parties has objective circumstances that impede the fulfillment of the obligations taken, the crime cannot be qualified as fraud (Regulatory Resolution of the Supreme Court of the Republic of Kazakhstan dated June 29, 2017 No. 6 "On Judicial Practice in Fraud Cases").

Since it is often difficult to establish the circumstances that indicate the intent to deceive, the Supreme Court tried to give an indicative list of such situations. Thus, paragraph 11 of the regulatory decree clarifies that the presence of intent aimed at embezzlement through fraud under contractual obligations may be indicated by a combination of such circumstances as the person's deliberate lack of real financial and other material possibilities (material and technical equipment, labor collective, etc. .) to fulfill the obligation taken, or the necessary license, permission to carry out activities aimed at fulfilling the obligations under the contract, whether Collecting forged constituent documents or letters of guarantee, hiding information about the presence of debts or pledge of property, entering into knowingly non-executable contracts and others (Regulatory Resolution of the Supreme Court of the Republic of Kazakhstan dated June 29, 2017 No. 6 "On Judicial Practice in Fraud Cases").

However, according to some scholars, the distinction between fraud and civil tort is required only when signs of fraud have not been proven, namely: methods of committing a crime, signs of embezzlement, premeditated intent, then the existing contractual relations are civil legal tort without forming a crime. In other cases, such a distinction is not required, since criminal prosecution does not exclude the possibility of civil liability (Khabarov, 1999:98).

We believe that this point of view deserves attention and is consistent with the spirit of the law. Since, based on the principle of the presumption of innocence, if the criminal prosecution authorities have not established reliable evidence in the actions of a person showing signs of fraud or breach of trust, there is no reason to 
involve a person for fraud.

We believe that this point of view deserves attention and is consistent with the spirit of the law. Since, based on the principle of the presumption of innocence, if the criminal prosecution authorities have not established reliable evidence in the actions of a person showing signs of fraud or breach of trust, there is no reason to involve a person for fraud.

In this regard, an important sign of the objective side associated with the occurrence of intent to "non-performance of contractual obligations" is the establishment of the end of fraud. In addition, it should be borne in mind that the law ambiguously determines the end of fraud and its varieties. These circumstances are important when qualifying material and formal elements of a crime.

According to paragraph 8 of the Regulatory Resolution of the Supreme Court of the Republic of Kazakhstan No. 6 of June 29, 2017 "On Judicial Practice in Fraud Cases", if fraud is committed in the form of acquiring the right to other people's property, the crime is considered to have been completed from the moment the guilty has a legally secured ability to possess, to use and dispose of other people's property as their own, after proper registration, certification or registration of this right (Regulatory Resolution of the Supreme Court of the Republic of Kazakhstan dated June 29, 2017 No. 6 "On Judicial Practice in Fraud Cases").

Fraud is recognized to be complete from the moment when the stolen property was seized and transferred to the unlawful possession of the perpetrator or other persons, and they received a real opportunity to own, use or dispose of it as they see fit as their own (Regulatory Resolution of the Supreme Court of the Republic of Kazakhstan dated June 29, 2017 No. 6 "On Judicial Practice in Fraud Cases").

Thus, based on the data of the explanations of the Regulatory Resolution in cases of fraudulent actions aimed at acquiring the right to own, use and dispose of another's property as your own, the crime will be considered completed when the person received a document authorizing him with this right, even if it does not took advantage of this right.

In other cases, the end of the fraud comes only when the person actually took possession of the property. Discussion of the conditions of the transfer, giving a formal consent to the transfer of property, other similar actions do not contain the composition of the completed fraud, and can only be considered an attempt.

\section{Conclusion}

Thus, the analysis of the studied sources, the current legislation and the practice of its application leads to the following conclusions.

1) Along with the active form of deception, there is also a passive deception, consisting in keeping silent about certain circumstances or information that should have been communicated before the conclusion of the transaction. At the same time, as a rule, a person must be mistaken about the facts that are important for making a decision on the transfer of property or the right to it.

2) The presence of a violation of the terms of the contract, even if they are significant, does not yet indicate the presence of the intent to deceive the counterparty. Failure to comply with the conditions may arise for various reasons, both objective and subjective. At the same time, if at the time of the conclusion of the contract or when preparing it, no fraudulent actions were carried out, then criminal prosecution under art. 190 of the Criminal Code of the Republic of Kazakhstan should be declared illegal.

3) A mandatory condition for criminal liability for fraud is the presence of a body of evidence that indicates that fraudulent perpetrators were committed at the time of the transaction or preceded the transfer of this property or the acquisition of the right to it and are causally related on the property.

4) Fraud can have both material and formal offense.

With the material composition, the moment of termination is the state when the stolen property was seized and transferred into illegal possession of the perpetrator or other persons, and they received a real opportunity to own, use or dispose of it as they see fit as their own.

With a formal composition, the moment of termination is the state when a person received a document granting him the right to own, use and dispose of another's property as his own, even if it did not use it.

5) Since the extent of the damage and the extent of the consequences are different, we consider it logical to change the approach to sanctions of articles providing for punishment for fraud. It seems expedient to introduce in the Criminal Code of the Republic of Kazakhstan new, qualifying elements of criminal offenses related to fraud. 


\section{References}

A woman deceived people for 350 million was convicted, but banks still demand repayment of loans from victims in Astana. (2018). Retrieved from https://zonakz.net/2018/04/26/obmanuvshaya-lyudej-na-t350-mln-zhenshhina-osuzhdena-odnako-banki-dosix-por-trebuyut-pogasheniya-kreditov-s-postradavshix-v-astane

Borchashvili, I. Sh. (2015). Commentary to the Criminal Code of the Republic of Kazakhstan. Almaty.

Borovkov, A. A. (2018). Fraud in the sphere of business activity (p. 5-7 of article 159 of the Criminal Code of the Russian Federation): problems of criminal law regulation and qualification. Krasnoyarsk.

Borzenkov, G. N. (1971). Responsibility for fraud. Qualification issues. Moscow: Urid.lit.

Brilliantov, A. V. (2015). Criminal law of Russia. Parts General and Special. Moscow: Prospect.

Dobrota, L. (2016). Stealing, so billions. Kazhahstanskaya Pravda.

Emelyanova, E. A. (2013). Informational nature of market manipulation. Bulletin of St. Petersburg University. Pravo, (3), 23-31.

Enshina, I. (2015, May 6). Realtors: work within the law. Retrieved from http://www.zakon.kz/4709422-rijeltory-rabotat-v-ramkakh-zakona.html

Foynitski, I. Ya. (1871). Fraud under the Russian law. Comparative study. St. Petersburg: Obschestvennaya polza, 1 .

Fraudsters in North-Kazakhstan region cheat residents with the help of popular portals and participation in sweepstakes. $\quad$ Retrieved from https://newtimes.kz/obshchestvo/76099-moshenniki-v-sko-obmanyvayut-zhitelej-pri-pomoshchi-populyarn ykh-portalov-i-uchastiya-v-rozygryshakh

Gelfer, M. A. (1987). Crimes against personal property of citizens. Moscow.

In Karaganda, realtors-fraudsters appeared in court. Retrieved from https://www.youtube.com/watch?v=k3A-Sm-RZbE

Khabarov, A. V. (1999). Property Offenses: The Impact of Civil Law. Tumen.

Khanov, T. A., Bakishev, K. A., \& Veselskaya, N. R. (2017). Differentiation of civil and criminal legal relations. Aktual'nyye problemy gumanitarnykh i yestestvennykh nauk, 2(2), 14-18.

Khilyuta, V. V. (2007). Truth silence as a passive form of fraudulent deception. Ugolovnoe pravo, (3), 68-72.

Khilyuta, V. V. (2009). Signs of fraudulent deception in the theory and practice of criminal law. Criminological Journal of the Baikal State University of Economics and Law, (2), 13-21.

Khilyuta, V. V. (2017). Borders and content of passive fraudulent deception. Ugolovnoe pravo, (3).

Kiseleva, I. A. (2013). Criteria for distinguishing fraud in the field of business activity and civil tort. Bulletin of the Nizhny Novgorod University. N.I. Lobachevsky, (3), 87-90.

Law of the Republic of Kazakhstan dated December 4, 2015 No. 434-V LRK "On Government Procurement". Retrieved from https://online.zakon.kz/document/?doc_id=34050877

Law of the Republic of Kazakhstan on November 24, 2015 No. 418-V “On Informatization”. Retrieved from https://online.zakon.kz/document/?doc_id=33885902

Mirochnik, A. S., \& Borovkov, A. A. (2017). Non-fulfillment of contractual obligations as a sign of business fraud. Zhurnal Rossiyskogo prava, 3(243), 92-100.

Regulatory Resolution of the Supreme Court of the Republic of Kazakhstan dated June 29, 2017 No. 6 “'On Judicial Practice in Fraud Cases". Retrieved from https://online.zakon.kz/document/?doc_id=37192456

Statistical reporting in the Republic of Kazakhstan. Prosecutor General's Office of the Republic of Kazakhstan. Period of $2012-2017$.

The verdict of the Leninsky District Court of Orenburg on March 12, 2013 in the case of 1-101/2013. Retrieved from http://sudact.ru/regular/doc/rlrXKJyyfNmY

The verdict of the magistrate of the court area No. 5 of the Central District of Barnaul dated March 14, 2013 in case No. 1-9 / 2013. Retrieved from http://sudact.ru/regular/doc/rlrXKJyyfNmY

Togaibaeva, S. S., Togaibaev, A. I., Khanov, T. A., Sikhimbayev, M. R., \& Rustemova, G. R. (2016). Criminal 
liability for illegal actions concerning insider information in the Republic of Kazakhstan. International Journal of Environmental and Science Education, (17), 10197-10209.

Up to 10 credits per person: case details. (2018). Retrieved from https://qostanay.tv/obshchestvo/do-10-kreditov-na-cheloveka-podrobnosti-dela-o-moshennichestve-v-astane

Veklenko, S. V., \& Petrov, S. A. (2011). Hypnosis suggestion as a means of fraudulent deception. Bulletin of the Voronezh Institute of the Ministry of Internal Affairs of Russia, (1), 10-13.

Vladimirov, V. A. (1974). Qualification of personal property theft. Moscow.

Yani, P. S. (2015). Special types of fraud. Zakonnost, 6(968), 19-23.

Zhalinskiy, A. E. (1999). On the relationship between civil and criminal legislation in the field of economics. Gosudarstvo i parvo, (12), 47-52.

\section{Copyrights}

Copyright for this article is retained by the author(s), with first publication rights granted to the journal.

This is an open-access article distributed under the terms and conditions of the Creative Commons Attribution license (http://creativecommons.org/licenses/by/4.0/). 